sept points : I. L'Éducation de Base est une technique de progrès matériel; 2. Elle n'est pas un succédané de l'enseignement, mais les deux peuvent s'aider à progresser mutuellement; 3. Elle est une formule de politique sociale utile au développement des communautés rurales; 4. Ne pas imposer, orienter; 5 . Nécessité d'une étude préalable au milieu; 6. Utiliser les dirigeants; 7 . Lier l'Éducation de Base et les plans de développement économique. En conclusion, M. Deschamps dit que le terme employé n'etait pas extrêmement juste, et que les Noirs s'imaginaient qu'on veut leur apporter une éducation au rabais et leur éviter la scolarisation. Il rappelle qu'il s'agit de tout un processus tendant à l'élévation du niveau de vie des populations, un procédé de promotion économique et sociale des populations rurales qui peut leur permettre de 'faire du paysan noir un paysan du XX' $\mathrm{XXècle}^{\mathrm{e}}$.

\title{
Le Prix Lovania
}

Lovania avait organisé un grand concours ouvert aux thétoriciens des établissements scolaires du Congo Belge; le sujet avait été ' La vie du Dr. Schweitzer'. Des participations étaient parvenues de Léopoldville, d'Élisabethville et de Bukavu, tant des athénées que des collèges ou des instituts d'enseignement officiel laïc ou congréganiste ou libre. Le jury, siégant à Élisabethville, sous la présidence de M. G. Verfaillie, avait couronné les deux contributions suivantes: Alexis de Palhen, du Collège Notre-Dame de la Victoire à Bukavu, ${ }^{\text {er }}$ prix; Esther Vamos, de l'Institut Marie-José à Élisabethville, $2^{\text {me }}$ prix. Les textes paraîtront successivement dans les numéros 36 et 37 de la revue Lovania.

\section{Central African Archives}

THE report of the Chief Archivist, Southern Rhodesia, for the years 1949- $\$ 4$, published in 1955, is the last report issued by the Archives as a Southern Rhodesian Agency: it now functions as a department of the Federation of Rhodesia and Nyasaland.

The present report covers a period of considerable development and expanding activity. It describes the work carried out in dealing with requests for information from government departments, the press, and private individuals; it gives an account of the collection of valuable historical manuscripts-in particular the important collection of Livingstone papers. Letters and diaries of the earlier missionaries have also provided valuable historical records: many of these have been presented to the Archives, others have been microfilmed.

The Central African Archives also possesses a research library which is available to accredited scholars. It includes a considerable collection of historical works-some of them rare early publications, a comprehensive collection of church and mission publications from the earliest times to the present day, as well as newspapers and periodicals. Copies of almost all printed matter published in the Federation must be deposited in the Archives, and in addition there is an annual vote for the purchase of books relating to Central Africa.

By means of its publications-notably the Oppenheimer Series-the Archives has made a considerable body of historical documents available to a wide public, and now it has in preparation the publication of earlier documents including Portuguese material (See Africa, xxv. 2, p. I8I).

The Archives has also organized historical exhibitions, particularly on the occasion of the Nyasaland Diamond Jubilee in $195 \mathrm{I}$, the Southern Rhodesia Diamond Jubilee in 1950 , and the birth of Cecil Rhodes, 1953.

In future, the Central African Archives will perform two distinct functions. The management of records will be carried out through centres in the three territories of the Federation, while the Archives headquarters will become the centre for research. 